\title{
Complete transposition of great arteries with coarctation of aorta
}

\author{
ORNELla MILANESI, GAETANO THIENE, ROBERTA M BINI, PIERO A PELLEGRINO \\ From the Department of Pediatrics and the Department of Pathology, University of Padua, Padua, Italy
}

SUMMARY Complete transposition of the great arteries with ventricular septal defect and coarctation or atresia of the aortic arch is a relatively rare anatomoclinical entity and in general not well understood. This association accounted for six out of 50 cases $(12 \%)$ of our clinical experience and six out of 64 cases $(9 \%)$ of the post-mortem series of complete transposition. Relevant clinical manifestations were cyanosis, early and pronounced congestive heart failure, with a decrease in amplitude of femoral pulses and, in the most severe cases, isolated left ventricular hypertrophy on the electrocardiogram. Inlet or outlet right ventricular obstruction and pulmonary artery dextroposition are the pathological substrates of unequal partitioning of the blood stream in favour of the pulmonary artery and ductus arteriosus, probably accounting for fetal underdevelopment of the aortic arch. The medical and surgical prognosis of these cases is definitely poor.

Obstructive lesions of the aortic arch are usually associated with concordant atrioventricular and ventriculoarterial connection. They may, however, also be present in complete transposition of the great arteries (discordant ventriculoarterial connection with atrioventricular concordance), but they have only sporadically been described in the published reports. ${ }^{1-5}$

It is the purpose of this paper to report our experience with patients affected by complete transposition of the great arteries and coarctation of the aorta. The clinicopathological features of these cases are sufficiently distinctive to indicate that this complex of malformations is a real and not so rare anatomoclinical entity.

\section{Subjects}

Among 50 consecutive cases of complete transposition of the great arteries seen at the Pediatric Department of the University of Padua, between June 1975 and June 1980 , six (12\%) were found to have obstructive lesions of the aortic arch. There were five male and one female patient (Table 1), varying in age from 1 to 55 days (mean 18 days). In three the diagnosis was made by cardiac catheterisation and angiocardiography, five died (cases 1 to 5, Table 1) and came to necropsy, one is still alive (case 6, Table 1). Reviewing our anatomical collection, another specimen (case 7, see Table 3) was found with this association. The incidence in our necropsy series was $9 \%$ (six out of 64 hearts with complete transposition of the great arteries). Only those cases were considered with the pulmonary artery arising mostly $(>50 \%)$ from the left ventricle and with the aorta arising entirely from the right ventricle; accordingly cases with double outlet right ventricle were excluded.

\section{CLINICAL FEATURES}

The clinical data are summarised in Table 1. All six patients presented with signs of congestive heart failure and cyanosis; in three the brachial and femoral pulses were equal and normal in amplitude, while in the others the femoral pulses were either absent or very weak; differential cyanosis was never observed.

In the electrocardiogram two out of six showed isolated left ventricular hypertrophy (Fig. 1, case 2) and two had biventricular hypertrophy; in one there was right ventricular hypertrophy and in the sixth the electrocardiogram was normal, when first seen at 1 day of age.

The chest $x$-ray showed cardiothoracic ratio varying from 0.58 to 0.78 and increased pulmonary vascularity in all the patients. An M-mode echocardiogram was recorded in one instance (Fig. 2, case 3): the right ventricular dimension was reduced; there were two atrioventricular valves with continuity between the posterior one and the pulmonary artery; the anterior great artery (aorta) was decreased in diameter.

Three patients (cases 4 to 6) underwent cardiac catheterisation (Table 2). The oxygen saturation 

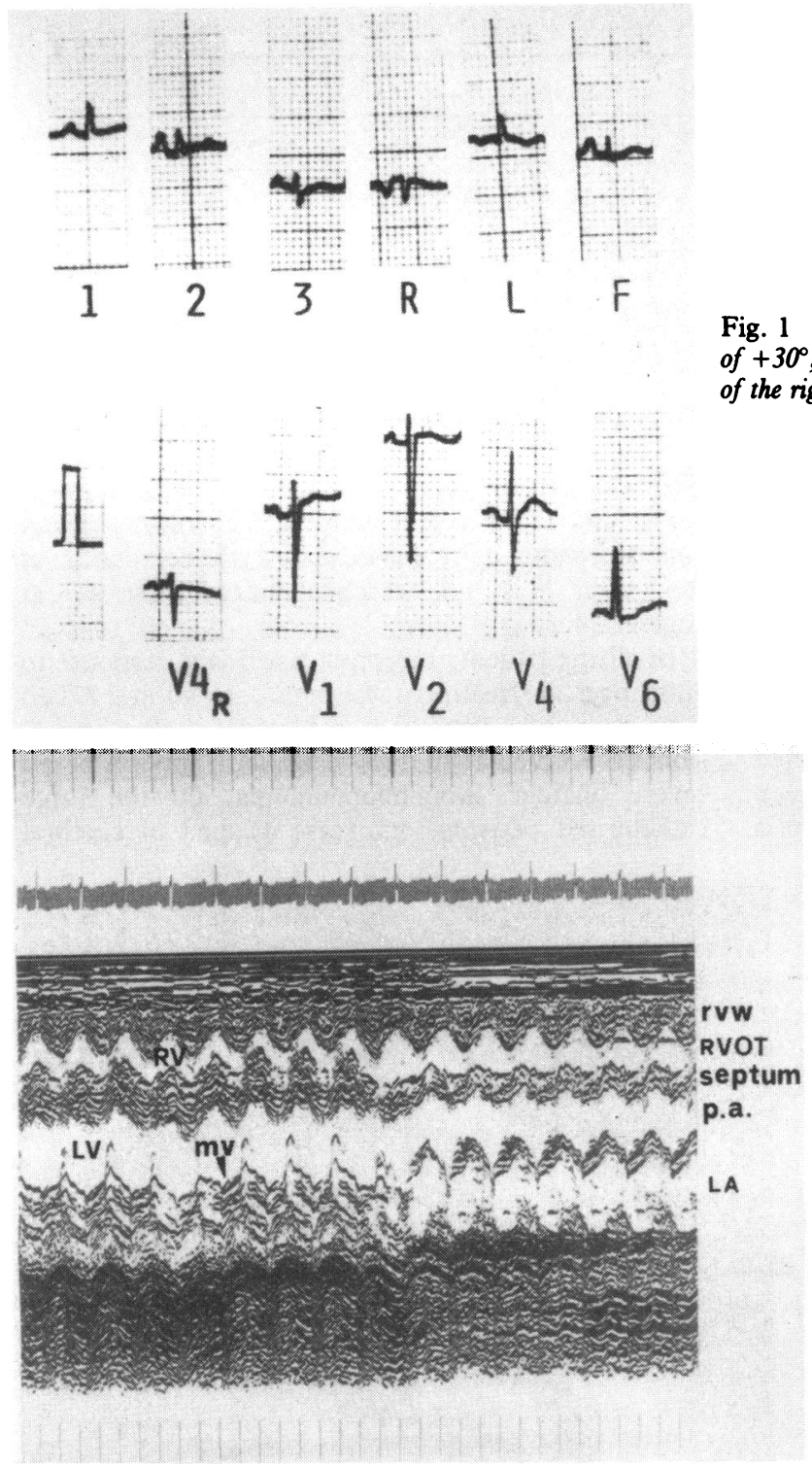

Table 1 Clinical data

\begin{tabular}{|c|c|c|c|c|c|c|c|c|c|}
\hline \multirow{2}{*}{$\begin{array}{l}\text { Case } \\
\text { No. }\end{array}$} & \multirow[t]{2}{*}{ Sex } & \multirow{2}{*}{$\begin{array}{l}\text { Age } \\
\text { on admission }\end{array}$} & \multirow[t]{2}{*}{ Cyanosis } & \multirow[t]{2}{*}{$C H F$} & \multirow{2}{*}{$\begin{array}{l}\text { Femoral } \\
\text { pulses }\end{array}$} & \multicolumn{2}{|c|}{ Electrocardiogram } & \multicolumn{2}{|c|}{$X$-ray } \\
\hline & & & & & & $L V H$ & $R V H$ & $C / T$ & $\begin{array}{l}\text { Pulmonary } \\
\text { vascular markings }\end{array}$ \\
\hline $\begin{array}{l}1 \\
2 \\
3 \\
4 \\
5 \\
6 \\
7 \star\end{array}$ & $\begin{array}{l}M \\
M \\
M \\
M \\
F \\
M \\
M\end{array}$ & $\begin{array}{l}1 \mathrm{~d} \\
6 \mathrm{~d} \\
15 \mathrm{~d} \\
55 \mathrm{~d} \\
30 \mathrm{~d} \\
1 \mathrm{~d} \\
5 \mathrm{mth}\end{array}$ & $\begin{array}{l}1^{+} \\
1^{+} \\
3^{+} \\
1^{+} \\
2^{+} \\
2^{+} \\
-\end{array}$ & $\begin{array}{l}3^{+} \\
3^{+} \\
2^{+} \\
2^{+} \\
3^{+} \\
1^{+} \\
-\end{array}$ & $\begin{array}{l}\text { Very weak } \\
\text { Absent } \\
\text { Normal } \\
\text { Normal } \\
\text { Normal } \\
\text { Weak } \\
\text { - }\end{array}$ & $\begin{array}{l}\text { Yes } \\
\text { Yes } \\
\text { Yes } \\
\text { No } \\
\text { Yes } \\
\text { No } \\
-\end{array}$ & $\begin{array}{l}\text { No } \\
\text { No } \\
\text { Yes } \\
\text { Yes } \\
\text { Yes } \\
\text { No } \\
-\end{array}$ & $\begin{array}{l}0.65 \\
0.78 \\
0.60 \\
0.60 \\
0.67 \\
0.58 \\
-\end{array}$ & $\underline{\uparrow}$ \\
\hline
\end{tabular}

*Other clinical data not available.

Abbreviations: LVH, left ventricular hypertrophy; RVH, right ventricular hypertrophy; $\mathrm{C} / \mathrm{T}$, cardiothoracic ratio; $\mathrm{CHF}$, congestive heart failure.
Fig. 1 Case 2. Electrocardiogram, showing a $Q R S$ axis of $+30^{\circ}$, left ventricular hypertrophy, and underdevelopment of the right ventricular electrical forces.

Fig. 2 Case 3. M-mode echocardiogram showing decreased right ventricular dimension and mitropulmonary continuity. The anterior wall of the pulmonary artery is entirely aligned with the interventricular septum.

Abbreviations: row, right ventricular wall; RVOT, right ventricular outflow tract; p.a., pulmonary artery; $L A$, left atrium; $R V$, right ventricle; $L V$, left ventricle; mv, mitral valve. 
Table 2 Cardiac catheterisation data

\begin{tabular}{|c|c|c|c|c|c|c|c|c|c|}
\hline \multicolumn{10}{|c|}{ Pressure ( $m m H g$ ) } \\
\hline \multirow[b]{2}{*}{$\begin{array}{l}\text { Case } \\
\text { No. }\end{array}$} & \multirow[b]{2}{*}{$\begin{array}{l}R A \\
M\end{array}$} & \multirow[b]{2}{*}{$\begin{array}{l}R V \\
S / D\end{array}$} & \multirow[b]{2}{*}{$\begin{array}{l}\text { Ascending } \\
\text { aorta } \\
\text { S/D M }\end{array}$} & \multirow[b]{2}{*}{$\begin{array}{l}\text { Descending } \\
\text { aorta } \\
S / D M\end{array}$} & \multirow[b]{2}{*}{$\begin{array}{l}L A \\
M\end{array}$} & \multirow[b]{2}{*}{$\begin{array}{l}L V \\
S / D\end{array}$} & \multirow[b]{2}{*}{$\begin{array}{l}P A \\
S / D M\end{array}$} & \multicolumn{2}{|c|}{ After Rashkind procedure } \\
\hline & & & & & & & & $\begin{array}{l}R A \\
M\end{array}$ & $\underset{M}{L A}$ \\
\hline 4 & 6 & $80 / 15$ & $70 / 35$ & & 20 & $70 / 15$ & $\begin{array}{l}75 / 35 \\
55\end{array}$ & 10 & 13 \\
\hline 5 & 8 & $70 / 10$ & $\begin{array}{l}88 / 45 \\
60\end{array}$ & $\begin{array}{l}78 / 20 \\
41\end{array}$ & 8 & $65 / 10$ & $\begin{array}{l}75 / 25 \\
25\end{array}$ & & \\
\hline 6 & 3 & $80 / 4$ & $\begin{array}{l}80 / 40 \\
60\end{array}$ & & 5 & & & 0 & 0 \\
\hline
\end{tabular}

showed a significant left-to-right shunt at the ventricular level in all of them. Pulmonary arterial hypertension was present in the two cases (cases 4 and 5) in which the pulmonary artery was entered; in only one case (case 5) was the descending aortic pressure obtained, showing a systolic gradient of $10 \mathrm{mmHg}$ between ascending and descending aorta. In this case aortography showed a "stop" of the contrast medium at the aortic isthmus (Fig. 3a), which was interpreted as an atresia of the aortic arch, whereas the surgeon found a distinct coarctation. In all three patients a diagnosis of transposition of the great arteries with ventricular septal defect was made by right and left cineventriculography; in one (case 4) the coarctation of the aorta was not recognised clinically or at angiography.

In all the patients but one (case 6) the response to anticongestive treatment was poor. Cases 1 and 2 died three days and a few hours, respectively, after admission; case 3 died at $\mathbf{4 0}$ days of age with superimposed severe bilateral bronchopneumonia. Of the three catheterised patients, one (case 4) died of cerebral
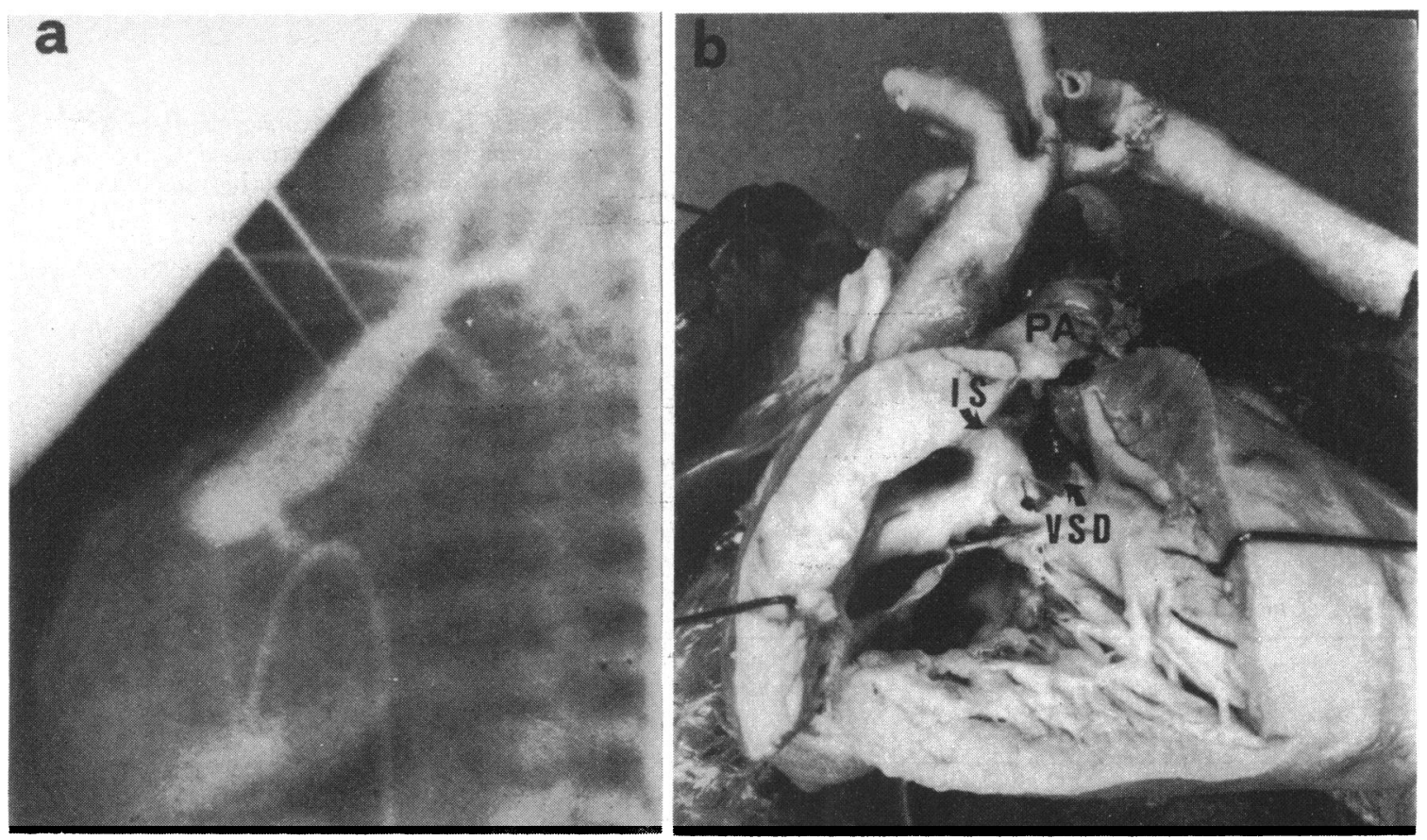

Fig. 3 Case 5. (a) Ascending aortography shows tubular hypoplasia of the aortic arch with complete interruption of the contrast medium at the level of the aortic isthmus. (b) The right ventricular view of the heart specimen discloses a subaortic infundibular stenosis caused by rightward displacement of the infundibular septum (IS), moderate dextroposition of the pulmonary artery $(P A)$, and the subpulmonary ventricular septal defect (VSD). Note the pulmonary banding and the surgically attempted relief of the aortic arch obstruction. 
$\mathrm{O}_{2}$ Saturation (\%)

\begin{tabular}{|c|c|c|c|c|c|c|c|c|c|c|}
\hline \multirow[b]{2}{*}{$S V C$} & \multirow[b]{2}{*}{$R A$} & \multirow[b]{2}{*}{$R V$} & \multirow[b]{2}{*}{$\begin{array}{l}\text { Ascending } \\
\text { aorta }\end{array}$} & \multirow[b]{2}{*}{$\begin{array}{l}\text { Descending } \\
\text { aorta }\end{array}$} & \multirow[b]{2}{*}{$L A$} & \multirow[b]{2}{*}{$L V$} & \multirow[b]{2}{*}{$P A$} & \multirow[b]{2}{*}{$P V$} & \multicolumn{2}{|c|}{ After Rashkind procedure } \\
\hline & & & & & & & & & $\overline{R V}$ & $\begin{array}{l}\text { Ascending } \\
\text { aorta }\end{array}$ \\
\hline $\begin{array}{l}53 \\
70 \\
20\end{array}$ & $\begin{array}{l}55 \\
75 \\
18\end{array}$ & $\begin{array}{l}72 \\
84 \\
29\end{array}$ & $\begin{array}{l}68 \\
36\end{array}$ & 94 & $\begin{array}{l}91 \\
98 \\
83\end{array}$ & $\begin{array}{l}95 \\
75\end{array}$ & 90 & $\begin{array}{l}96 \\
90\end{array}$ & 72 & \\
\hline
\end{tabular}

Abbreviations: RA, right atrium; RV, right ventricle; LA, left atrium; LV, left ventricle; PA, pulmonary artery; SVC, superior vena cava; $M$, mean pressure; $\mathrm{S} / \mathrm{D}$, systolic/diastolic pressure; $\mathrm{PV}$, pulmonary vein.

haemorrhage five days after operation (persistent ductus arterious ligation plus pulmonary artery banding); another (case 5) died at 2 months of age, 48 hours after operation (resection of coarctation with end to end anastomosis of the aorta, pulmonary artery banding, and persistent ductus arteriosus ligation); the third (case 6) is the only patient who has survived and is now awaiting operation after a second cardiac catheterisation.

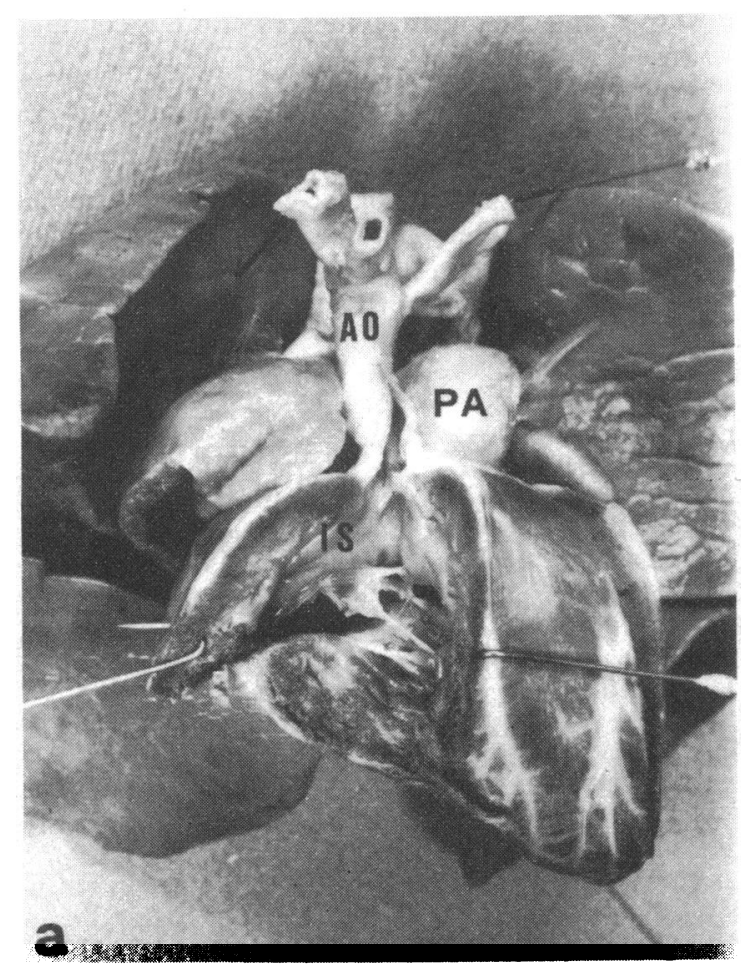

\section{NECROPSY FINDINGS}

The most relevant observations at necropsy are reported in Table 3 . Visceroatrial situs solitus, laevocardia, atrioventricular concordance, and ventriculoarterial discordance were present in all the cases. The ascending aorta was small and the pulmonary artery large, the ratio between the diameters of the pulmonary artery and ascending aorta being more than $1.5: 1$ in three cases. Patent or closing ductus arteriosus

Fig. 4 Case 2. (a) The right ventricle has a hypoplastic trabecular component and an obstructed aortic outflow resulting from anterior deviation of the infundibular septum (IS). Note the extreme dilatation of the pulmonary artery (PA) when compared with the small ascending aorta $(A O)$. (b) The view from the left ventricle shows the ventricular septal defect (VSD) caused by infundibuloventricular malalignment and mild dextroposition of the pulmonary artery. Note the atretic aortic arch (arrow) between the left carotid and left subclavian artery.

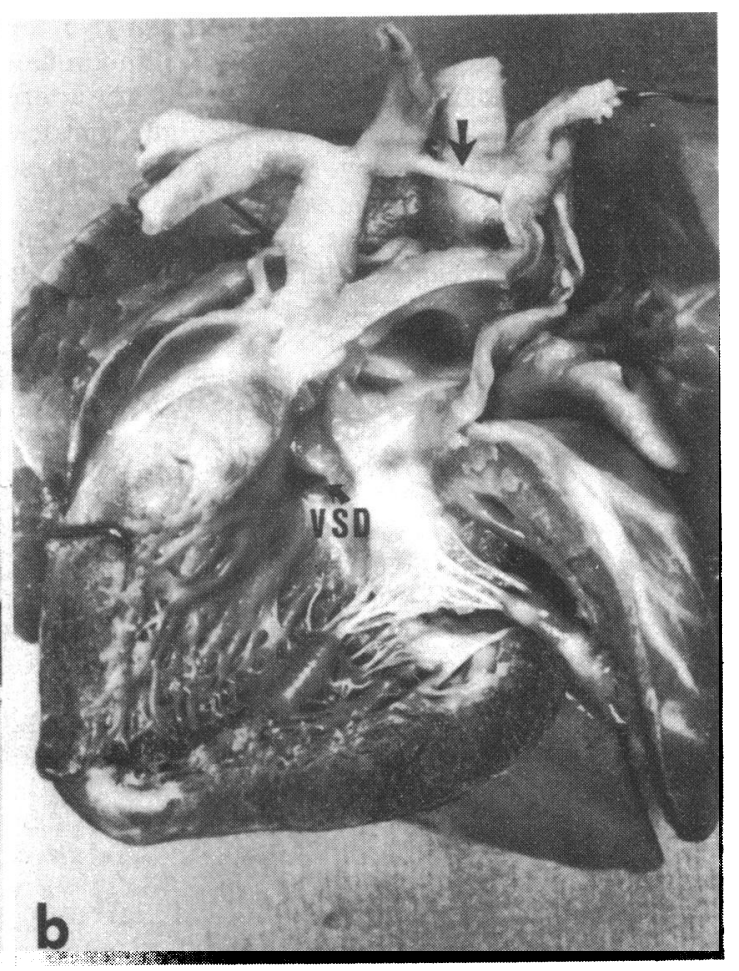


Table 3 Necropsy findings

\begin{tabular}{|c|c|c|c|c|c|c|c|c|}
\hline $\begin{array}{l}\text { Case } \\
\text { No. }\end{array}$ & $\begin{array}{l}P A / A o \\
\text { diameter } \\
\text { ratio }\end{array}$ & $\begin{array}{l}\text { Right ventricle } \\
\text { Inflow }\end{array}$ & $\begin{array}{l}\text { Trabecular } \\
\text { portion }\end{array}$ & Outflow & $V S D$ & $\begin{array}{l}\% P A \\
\text { dextroposition }\end{array}$ & $\begin{array}{l}\text { Aortic } \\
\text { arch } \\
\text { obstruction }\end{array}$ & $P D A$ \\
\hline 1 & $1 \cdot 7: 1$ & Normal & $\begin{array}{l}\text { Moderate } \\
\text { hypoplasia }\end{array}$ & Normal & $\begin{array}{c}\text { Subpulmonary } \\
\text { malalignment }\end{array}$ & $40 \%$ & $\underset{\text { type } A^{\star}}{\text { Atresia }}$ & Large \\
\hline 2 & $2: 1$ & Normal & $\begin{array}{l}\text { Severe } \\
\text { hypoplasia }\end{array}$ & $\begin{array}{c}\text { Subaortic } \\
\text { a stenosis }\end{array}$ & $\begin{array}{c}\text { Subpulmonary } \\
\text { malalignment }\end{array}$ & $10 \%$ & $\underset{\text { type } B^{\star}}{\text { Atresia }}$ & Large \\
\hline 3 & $1 \cdot 2: 1$ & Normal & Normal & Normal & $\begin{array}{c}\text { Subpulmonary } \\
\text { malalignment }\end{array}$ & $20 \%$ & $\begin{array}{l}\text { Preductal } \\
\text { coarctation }\end{array}$ & Closing \\
\hline 4 & $1 \cdot 3: 1$ & Normal & $\begin{array}{l}\text { Moderate } \\
\text { hypoplasia }\end{array}$ & $\begin{array}{c}\text { Subaortic } \\
\text { a stenosis }\end{array}$ & $\begin{array}{l}\text { Subpulmonary } \\
\text { malalignment }\end{array}$ & $15 \%$ & $\begin{array}{c}\text { Tubular } \\
\text { hypoplasia }\end{array}$ & Closingt \\
\hline 5 & $1 \cdot 5: 1$ & Normal & Normal & $\begin{array}{c}\text { Subaortic } \\
\text { stenosis }\end{array}$ & $\begin{array}{c}\text { Subpulmonary } \\
\text { malalignment }\end{array}$ & $30 \%$ & $\begin{array}{l}\text { Preductalt } \\
\text { coarctation }\end{array}$ & Closingt \\
\hline$\frac{6 \neq}{7}$ & $2: 1$ & $\begin{array}{l}\text { Very } \\
\text { stenotic }\end{array}$ & $\begin{array}{l}\text { Severe } \\
\quad \text { hypoplasia }\end{array}$ & $\begin{array}{c}\text { Moderate } \\
\text { a hypoplasia }\end{array}$ & $\begin{array}{l}\text { Perimembranous } \\
\text { VSD }\end{array}$ & - & $\underset{\text { type } A^{\star}}{\text { Atresia }}$ & Closing \\
\hline
\end{tabular}

${ }^{\star}$ Celoria and Patton classification. ${ }^{6}$

tSurgical observation.

¥ase 6 is still alive.

Abbreviations: PA, pulmonary artery; Ao, ascending aorta; VSD, ventricular septal defect; PDA, persistent ductus arteriosus.

was observed in four cases, while in two it had been surgically ligated. The aortic arch appeared atretic in three instances, type A of Celoria and Patton ${ }^{6}$ in two and type $B$ in one; preductal coarctation was present in two and tubular hypoplasia in one. All specimens had an associated ventricular septal defect. In five the defect was subpulmonary because of infundibuloventricular malalignment and the pulmonary artery was dextroposed, its origin from the right ventricle varying from 10 to $40 \%$ (Fig. 3b, 4). In three of these the infundibular septum showed an anterior displacement, creating subaortic narrowing. The right ventricle was underdeveloped in three hearts, mostly in its trabecular component.
In the sixth specimen, instead, the ventricular septal defect was small, perimembranous, and the pulmonary artery arose entirely from the left ventricle. The tricuspid valve appeared very stenotic and the right ventricle extremely hypoplastic (Fig. 5).

In all the cases mitro-pulmonary fibrous continuity was present.

\section{Discussion}

Complete transposition of the great arteries is usually classified into three physiological clinical entities: (1) simple transposition of the great arteries with intact ventricular septum characterised by conspicuous

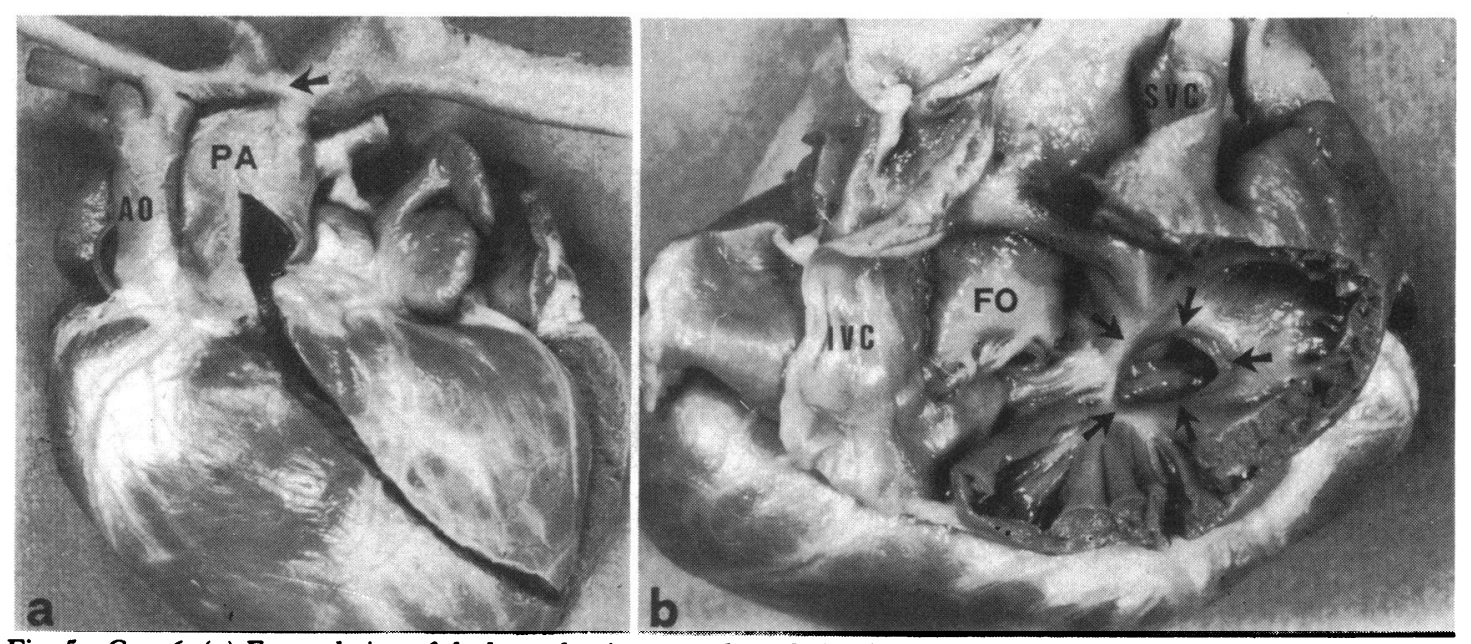

Fig. 5 Case 6. (a) External view of the heart showing severe hypoplasia of the aortic arch with preductal coarctation (arrow), hypoplastic ascending aorta $(A O)$, and dilated pulmonary artery $(P A)$. (b) View of the opened right atrium showing that the tricuspid orifice is very small (arrows) compared with the fossa ovalis (FO). The foramen ovale is restrictive and the superior $(S V C)$ and inferior (IVC) vena cavae are dilated. 
hypoxia, caused by lack of mixing between pulmonary and systemic circulation; (2) transposition of the great arteries with large ventricular septal defect in which signs of congestive heart failure predominate in the clinical picture; and (3) transposition of the great arteries with ventricular septal defect and pulmonary stenosis in which cyanosis is prominent, caused by decreased pulmonary blood flow, and the clinical findings parallel those in infants with tetralogy of Fallot.?

The syndrome of coarctation of the aorta in transposition of the great arteries has been considered extremely rare $^{8}$ and, accordingly, has never received sufficient attention. Our experience, together with other recent reports, ${ }^{10}$ suggest that aortic arch anomalies are not so rare and the clinical manifestations and the pathological findings of this association are suffciently distinctive as to be considered a separate nosographic entity among transposition of the great arteries.

Besides the presence of transposition of the great arteries and obstruction of the aortic arch, the following morphological features delineate this anatomical complex: (a) ventricular septal defect, always present, mostly subpulmonary and associated with dextroposition of the pulmonary artery; (b) mild to moderate right ventricular underdevelopment mainly of the trabecular component; and (c) right ventricular inflow, rarely, or outflow, more frequently, obstruction (caused by tricuspid stenosis or infundibular subaortic stenosis, respectively). Usually, the lower part of the systemic circulation is ductus-dependent.

From the clinical standpoint, cyanosis, early and severe congestive heart failure, and decreased amplitude of the femoral pulses characterise most of these patients. This picture of coarctation of the aorta in transposition of the great arteries is often associated with the presence of left ventricular hypertrophy on the electrocardiogram, either isolated $(2 / 6)$ or combined with right ventricular hypertrophy $(2 / 6)$. It is noteworthy that isolated left ventricular hypertrophy was observed just in those two cases with an atretic aortic arch and moderate to severe right ventricular hypoplasia. The decreased right ventricular electrical forces and the pressure and volume overload of the left ventricle account for this paradoxical electrocardiographic pattern in transposition of the great arteries.

Anterior displacement of the infundibular septum, as seen in three of our cases, has been suggested as a cause of subaortic stenosis in transposition of the great arteries, and obstruction of the aortic arch has also been described. ${ }^{5} 9{ }^{10}$ Unequal partitioning of the blood flow between the aorta and pulmonary artery in the presence of a ventricular septal defect may be advocated as the fetal pathogenetic mechanism for the underdevelopment of the aortic arch, as postulated for aortic arch anomalies in normally related great arteries." Preferential blood streaming toward the pulmonary artery and ductus arteriosus may also be the result of inlet obstruction of the right ventricle, as in our case 7 , or of dextroposition of the pulmonary artery, as in double outlet right ventricle with subpulmonary ventricular septal defect (TaussigBing), which is often associated with coarctation or interruption of the aorta.

In conclusion, we believe that, among transpositions of the great arteries, the form with aortic arch obstruction merits being viewed as a distinct physiological clinical type because it is relatively frequent and its pathological anatomy is distinctive.

This type of transposition is unfortunately associated with a worse clinical and surgical prognosis than is now the case in the other three major types.

\section{References}

1 Newcombe CP, Ongley PA, Edwards JE, Wood EH. Clinical, pathologic and hemodynamic considerations in coarctation of the aorta associated with ventricular septal defect. Circulation 1961; 24: 1356-66.

2 Elliott LP, Neufeld HN, Anderson RC, Adams P Jr, Edwards JE. Complete transposition of the great vessels. I. An anatomic study of sixty cases. Circulation 1963; 27: 1105-17.

3 Moller JH, Edwards JE. Interruption of aortic arch. Anatomic patterns and associated cardiac malformations. $A f R$ 1965; 95: 557-72.

4 Shaher RM. Complete transposition of the great arteries. New York: Academic Press, 1973: 176-9.

5 Van Praagh R, Bernhard WF, Rosenthal A, Parisi LF, Fyler DC. Interrupted aortic arch: surgical treatment. Am f Cardiol 1971; 27: 200-11.

6 Celoria GC, Patton RB. Congenital absence of the aortic arch. Am Heart f 1959; 58: 407-13.

7 Keith JD, Rowe RD, Vlad P. Heart disease in infancy and childhood. 3rd ed. New York: Macmillan, 1978: 595-6.

8 Moss AJ, Adams FH, Emmanouilides GC. Heart disease in infants, children and adolescents. 2nd ed. Baltimore: Williams \& Wilkins, 1977: 310.

9 Kurosawa H, Van Mierop LHS. The displacement of the infundibular septum in transposition of the great arteries with ventricular septal defect. World Congress of Paediatric Cardiology, London 1980 (abstract No 339).

10 Schneeweiss A, Motro M, Shem-Tov A, Neufeld HN. Subaortic stenosis: an unrecognized problem in transposition of the great arteries. Am $\mathcal{F}$ Cardiol 1981; 48: 336-9.

11 Rudolph AM, Heymann MA, Spitznas V. Hemodynamic considerations in the development of narrowing of the aorta. Am F Cardiol 1972; 30: 514-25.

Requests for reprints to Dr Ornella Milanesi, Clinica Pediatrica, Università degli Studi di Padova, Via Giustiniani 3, I-35100 Padova, Italy. 